\title{
Time Management and Building Strategy on Learning Process in Polytechnic
}

\author{
Iis Mariam*, Endah Wartiningsih, Nidia Sofa, Nining Latianingsih \\ Business Administration Department \\ State Polytechnic of Jakarta \\ Jakarta, Indonesia \\ *iis.mariam@bisnis.pnj.ac.id
}

\begin{abstract}
The impact of the current digital transformation is the change in work and type of work, innovation in the economy and individual empowerment also felt by students in higher education to become masters of technology in the learning process into new problems. This condition also has an impact on time management in the learning process carried out by students at the Polytechnic so that it can adjust learning patterns and become accustomed to mastering digital transformation. The purpose of this study is to analyze whether time management has an impact on learning outcomes? What strategies are used to make time management more productive in the learning process? The research method uses descriptive qualitative analysis, the unit of analysis is Polytechnic students totaling 100 people, with data collection techniques using interviews, participative observation and questionnaires. The results show that effective time management in learning activities by students is: learning tasks become more organized, learning activities more fun, can do unexpected tasks better and on time, flexibility in working on lecture assignments, determining learning patterns (agree: 64\%). Whereas in time management a learning strategy is needed (agree 67\%), a learning strategy becomes easier and more convenient, a strategy is needed in obeying work rules, there is division of tasks. These results indicate that the practical implications of effective time management in learning give regular, pleasant results, flexibility can be done by considering strategies and mastery of information technology.
\end{abstract}

Keywords—time management, strategy, learning process

\section{INTRODUCTION}

The current digital transformation has an impact on the learning process that must be carried out during the Covid-19 period while still following health protocols. The transformation in the learning process has an impact not only on teachers but also on students who have to adapt to the demands of learning needs. The learning process carried out by e-learning currently demands an effective and efficient use of time from both the teacher and learner. The problem that arises is that when you do not have a schedule to carry out a work activity, your time is not used optimally and does not provide a use value so that time becomes unproductive. Therefore, this study aims to analyze whether time management has an impact on learning outcomes? What strategies are taken for time management can provide more productive results in the learning process? Based on the problems and objectives of this research, the data analysis process related with research [1] that the role of teachers, leaders of academic institutions and human resources is to provide opportunities for teachers to improve knowledge, time management skills so that job satisfaction, work motivation, and professionalism are increased and meaningful. Time management used in the learning process will have an impact on effective results. Time management can be seen as a way of monitoring and evaluating, setting goals and utilizing time that gives positive results [2-6]. There is a relationship between time management and student perceptions and behavior [7], time management is an effort to optimize opportunities through skills and knowledge to carry out activities in an organization, including learning that provides useful values and results. The role of teachers, leaders of academic institutions and human resources is to provide opportunities for teachers to improve knowledge, time management skills so that job satisfaction, work motivation, professionalism increases and is meaningful [1,2].

\section{METHODS}

The method used in this research is mixed methods [8] where quantitative methods are used to determine the sample and qualitative methods to describe the results of the questionnaire received. The data collection techniques used a questionnaire with google form and literature study. The questionnaire uses a Likert scale which contains questions about time management planning, the strategies used in the application of time management and the impact of time management on the learning process. Selection of respondents using non-probability sampling [9] and determining the sample according to Slovin as follows:

Information:

$$
n=\frac{N}{\left(1+N e^{2}\right)}
$$

$\mathrm{N}$ is the number of samples, $\mathrm{N}$ is the total number of combinations while $\mathrm{E}$ is the sample error rate (sampling error). 
Referring to the Slovin formula, the following calculations are obtained:

$$
n=\frac{14.810 .469}{1+14.810 .469 \times(0,10)^{2}}
$$

Based on the Solvin formula, the maximum sample size is $10 \%$, which is 99 people rounded up to 100 people.

\section{ANALYSIS AND DISCUSSION}

Time management research conducted [7] on the relationship between time management (variable X1) and selfefficacy (Variable X2) and procrastination (Y), the results showed that time management and self-efficacy variables only contributed to the emergence of procrastination behavior by 21 . $3 \%$, while the teacher's ability to manage time is very high $(90.91 \%)$. [2] said that to make good time management requires a good determination of family life and organization and the effectiveness of using time can be achieved if you pay attention to the difference between urgent and important activities. This time management research involves the existence of a process of influence on perceptions, feelings, performance. Time management both objectives, monitoring and priorities have produced positive values [5]. The relationship between family conflicts with work, psychological pressure, workplace injuries, job compensation, lost work time, demoralized workers require organizations to help workers organize work well and provide positive support to workers' families [10-12]. Time management has an inverse relationship with self-management and productivity in organizations, it requires a pleasant work environment, a modern management approach that results in increased self-commitment [11]. The results of research [7] showed that students' perceptions of supervision were significantly correlated with the cumulative mean score but not and not significantly correlated between behavior and time management with differences in gender, qualification, age and program work. The results of this study are in common with studies from [6-7]. The results show that the learner before time management is implemented, it is necessary to make proper planning so that the results of time management provide useful values. Time management has an impact on learning tasks that are carried out more regularly (agree: 55\%) and this gives maximum results (Figure 1).

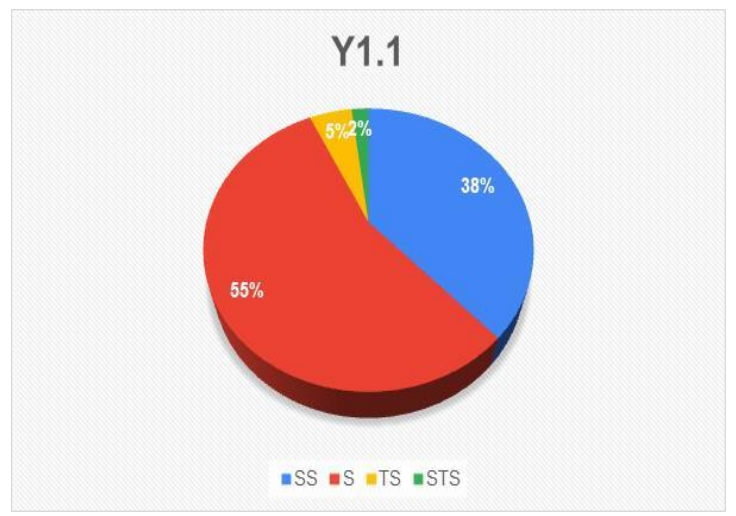

Fig. 1. Time management imfact on learning proces.
Time management has also made learners participate in learning activities more regularly (70\% agree), which means that time management has had a good impact on the learning process (Figure 2).

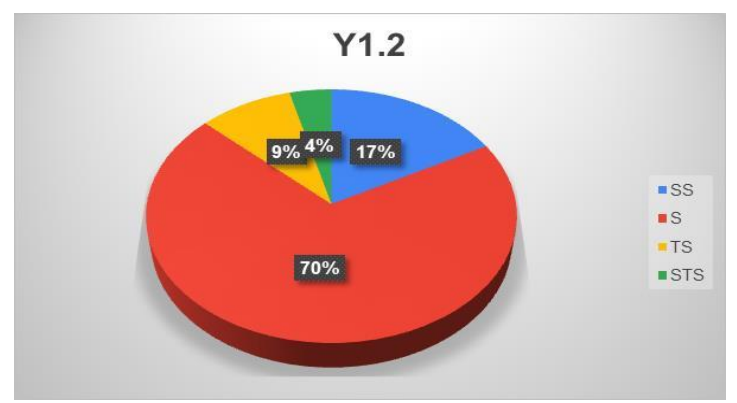

Fig. 2. Time management makes learning activities more organized.

Respondents said that $56 \%$ agreed with time management so that unexpected tasks could be done on time (Figure 3).

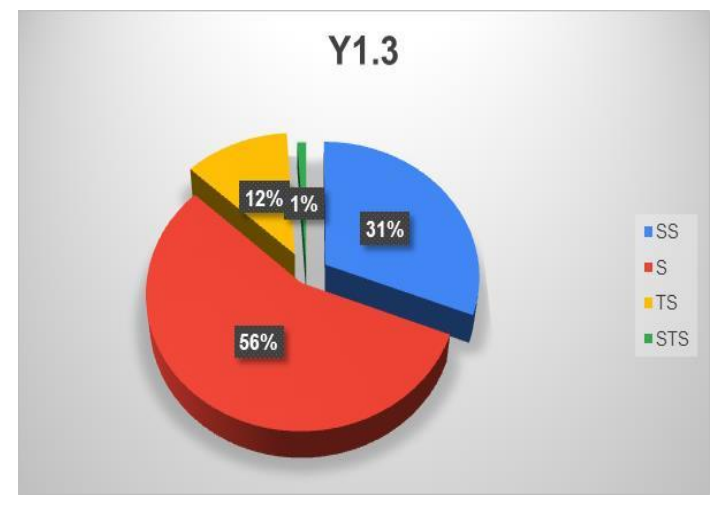

Fig. 3. Time management creates unexpected tasks.

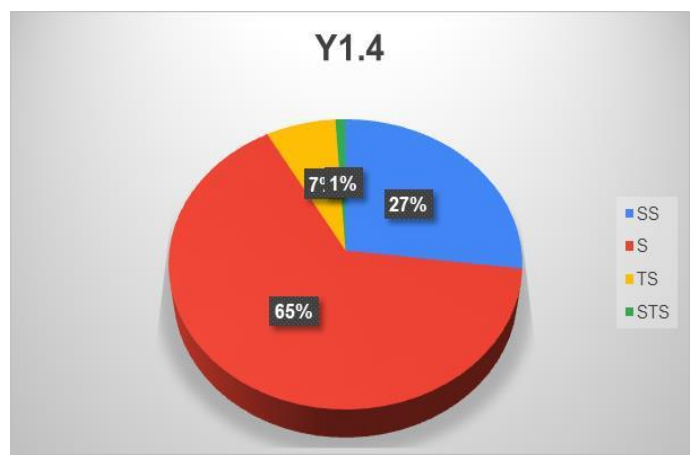

Fig. 4. Flexibility of time management.

Time management is also very important in determining patterns of learning and respondents $64 \%$ agree with the statement (figure 5). 


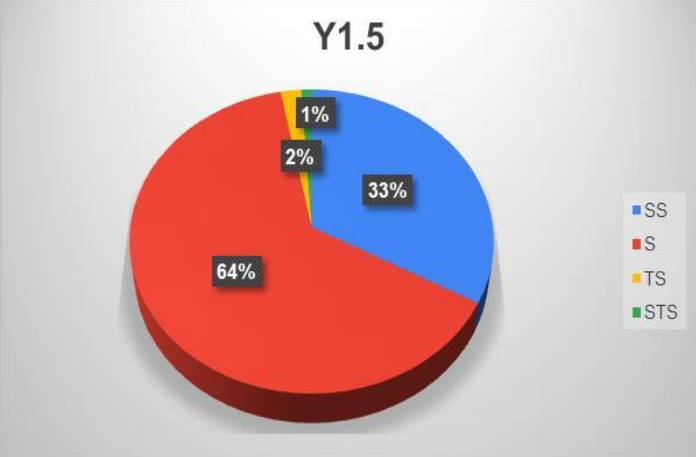

Fig. 5. Time management and course learning patterns.

Learning strategies are needed in the application of time management by $67 \%$ of respondents answered agree, $20 \%$ strongly agree. This shows that strategy is important in the application of time management and is relevant to the results of research [5] resulting in increased self-commitment [7,10]. The results of research show that perceptions of student supervision correlate significantly.

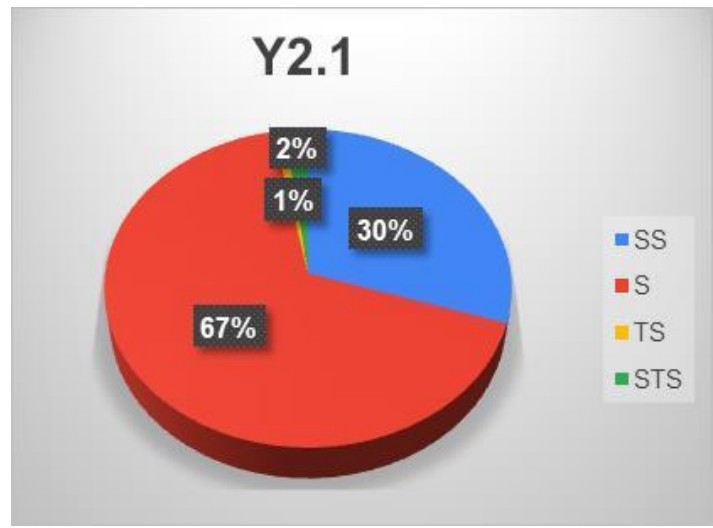

Fig. 6. Learning strategies in the application of time management.

Respondents agree (64\%) that learning strategies can be carried out easily and comfortably if the focus is on implementing an appropriate learning schedule.

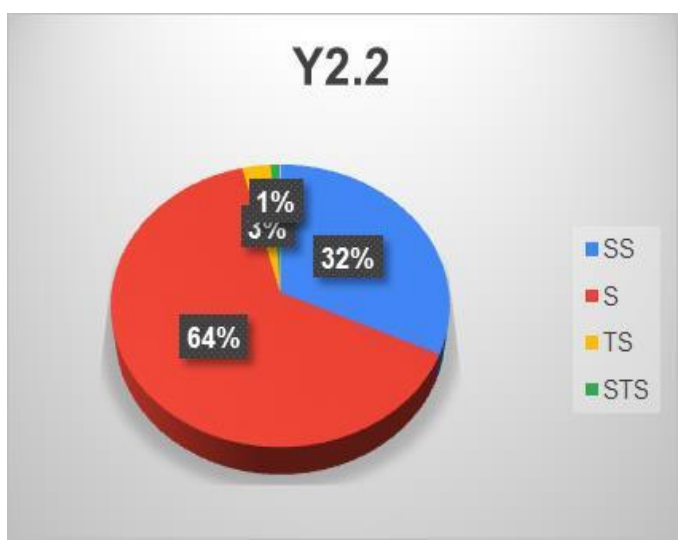

Fig. 7. Learning strategies are easy and comfortable.
TABLE I. IMPACT OF TIME MANAGEMENT IN LEARNING

\begin{tabular}{|l|l|l|l|l|}
\hline \multicolumn{1}{|c|}{ STATEMENTS SD } & $\begin{array}{c}\text { NA } \\
\mathbf{\%}\end{array}$ & $\begin{array}{c}\text { A } \\
\text { \% }\end{array}$ & SA \\
\hline $\begin{array}{l}\text { Time management that is not done } \\
\text { properly in completing lecture } \\
\text { assignments will result in frustration }\end{array}$ & 26 & 58 & 16 & 1 \\
\hline $\begin{array}{l}\text { Time management that is not done } \\
\text { properly will cause conflict in effective } \\
\text { learning }\end{array}$ & 25 & 71 & 3 & 1 \\
\hline $\begin{array}{l}\text { Time management that is carried out } \\
\text { during lectures will result in work } \\
\text { productivity }\end{array}$ & 30 & 68 & 1 & 1 \\
\hline $\begin{array}{l}\text { The number of responsibilities and } \\
\text { assignments that must be carried out } \\
\text { causes stress in learning }\end{array}$ & 50 & 44 & 6 & 0 \\
\hline $\begin{array}{l}\text { Time management that is not done } \\
\text { properly at the lecture site will cause } \\
\text { other psychological problems. }\end{array}$ & 23 & 65 & 12 & 0 \\
\hline
\end{tabular}

SD (strongly disagree), NA (not agree)

\section{A (agree), $\quad$ SA (strongly agree)}

From the table1 if time management not done properly, there will have negative impacts such as: frustration (agree: $58 \%$ ), stress (strongly agree: 50\%), psychological (agree: $65 \%$ ), personal conflict (agree: $71 \%$ ). In other sides if time management is carried out properly will increase work productivity (agree: 68\%) and bring positive impacts.

The limitation in this study, it is necessary to ask more specific in a questionnaire about how the work priority scale related to time management which is not conveyed in this research.

\section{CONCLUSIONS AND SUGGESTIONS}

\section{A. Conclusion}

- Time management can help the student learning process become easier, more focused, organized and fun;

- The results of time management research are associated with strategies relevant to previous research, namely: providing positive results to working families, increasing self-commitment refer to Rombe [13], time management having a significant positive correlation with student supervision [7];

- Time management that is not done properly can cause negative impacts (conflict, psychological, frustration, stress) and positively by increasing work productivity.

\section{B. Suggestions}

- Time management that is carried out in the learning process should be given from the beginning when participants learn how important the impact is to be positive or negative and contributes directly to the mastery of knowledge and skills; 
- The management team is not only carried out in an educational pattern but also is very important in determining the priority scale in doing work.

\section{REFERENCES}

[1] Z. Sahito and P. Vaisanen, "Effect of Time Management on the Job Satisfaction and Motivation of Teacher Educators: A Narrative Analysis," International Journal of Higher Education, vol. 6, no. 2, 2017.

[2] A.A. Gea, "Time Management: Menggunakan Waktu Secara Efektif dan Efisien," Humaniora, vol. 5. no. 2, pp. 777-785, 2014.

[3] B. Eilan and I. Aharon, "Students Planning in the Process of SelfRegualated Learning," Contemporary Educational Psychology, vol. 28, pp. 30-34, 2003.

[4] M.A.G. Peeters and C.G. Rutte, "Time Management behaviour as a Moderator for the Job-Demand-Control Interaction," Journal of Occupational Health Psychology, vol. 10, pp. 64-75, 2005.

[5] B.J.C. Claessens, W. van Eerde, C.G. Rutte and R.A. Roe, "A Review of The Time Management Literature," Personnel Review, vol. 36, no. 2, pp. 255-276, 2007.
[6] K.I. Sandra and M.As'ad Djalali, "Manajemen Waktu, Efikasi-Diri dan Prokrastinasi," Persona, Jurnal Psiklogi Indonesia, vol. 2. no. 3, pp. 217 222, 2013.

[7] R.V. Adams and E. Blair, "Impact of Time Management Behaviors on Undergraduate Engineering Students' Performance,” SAGE Open, 2019.

[8] J.W. Creswell and V.L.P. Clartk, Designing and Conducting Mixed Methods Research. USAGE, 2017

[9] Sugiyono, Metode Penelitian Kuantitatif, Kualitatif, dan R \& D. Bandung: Alfabeta, CV, 2017.

[10] R.J. Ferrari and W. McCown, "Procastination Tendencies Among Obsessive-Compulsives and Their Relatives," Journal of Clinical, Prsychology, vol. 50, no. 2, pp. 162-167, 1994

[11] C.J. Konig and M. Kleinmann, "Time Management Problems and Discounted Utility," 2010

[12] V.S. Major, K.J. Klein, and M.G. Ehrhart, "Work Time, Work Interference with Family, and Psychological Distress," Journal of Applied Psychology, vol. 87, pp. 427-436. 2002.

[13] M.L.M. Rombe, "Efective Time and Self Management, Environment and Productivity in an Organization," Science Journal of Business and Management, vol. 4, no. 6, pp. 204-211, 2016. 